\title{
Variability of breeding system, caryopsis microstructure and germination in annual and perennial species of the genus Brachypodium P. Beauv.
}

\author{
Romuald Kosina $\cdot$ Paulina Tomaszewska
}

Received: 13 January 2015/ Accepted: 21 July 2015/Published online: 9 August 2015

(C) The Author(s) 2015. This article is published with open access at Springerlink.com

\begin{abstract}
The basis of any patterns of variation in plant populations is the breeding system they express. In the genus Brachypodium, the breeding system ranges from autogamy in facultatively chasmogamic Brachypodium distachyon to allogamy in obligatory chasmogamic $B$. pinnatum. B. distachyon and $B$. sylvaticum appeared to be extremes with respect to dormancy and germination behaviour. Winter and facultatively biennial forms of the annual $B$. distachyon expressed an intermediate dormancy behaviour towards perennial species. Perennial species such as B. pinnatum, B. phoenicoides, $B$. rupestre and B. sylvaticum demonstrated allogamic behaviour and were highly dormant. The storage potential of hemicelluloses in endosperm cell walls and suberinphenolic synthesis in testa and pigment strand differ distinctly between annuals and perennials. The suberized glumellae base and caryopsis attachment restrict the growth of coleorhiza and can change growth relationships between root and coleoptile. Coleorhizal hairs facilitating water capillary adhesion to an embryo are developed in both types of Brachypodium
\end{abstract}

\footnotetext{
R. Kosina $(\bowtie)$

Plant Speciation Group, Institute of Environmental

Biology, University of Wrocław, Przybyszewskego 63/77,

51-148 Wrocław, Poland

e-mail: kosina@biol.uni.wroc.pl

P. Tomaszewska

Institute of Experimental Biology, University of Wrocław,

Kanonia 6/8, 50-328 Wrocław, Poland
}

species, but in perennial types they are less efficient. The pattern of development of coleorhizal hairs distinguishes Brachypodium species from members of the tribe Triticeae. The coleorhizal hairs are less developed in Triticeae. This trait is variable at the populational level, especially in heterozygous populations (B. phoenicoides). Both extremes in terms of dormancy, i.e. B. distachyon and B. sylvaticum, revealed inter- and intrapopulational variability of germination.

Keywords Annuals - Brachypodium $\cdot$ Breeding system · Dormancy $\cdot$ Germination $\cdot$ Perennials $\cdot$ Seed structure

\section{Introduction}

The panmictic status of heterozygotes in a population with randomly exchanged genes is rarely found in nature. Deviations from panmixis are caused by the small size of populations, their non-random distribution and isolation. A deficiency in heterozygotes can be caused by self-pollination of chasmogamic flowers (Richards 1986). Populations of Brachypodium Beauv. species are good examples of non-random frequencies of genotypes and phenotypes. A reduction in the frequency of heterozygotes may be realized in Brachypodium via autogamy or geitonogamy. This may occur in B. distachyon (L.) Beauv. and B. sylvaticum (Huds.) Beauv., which express high levels of self-compatibility 
(Khan and Stace 1999). In populations of perennials a degree of equilibrium between generative and vegetative reproduction has been noted, for instance in Brachypodium pinnatum (L.) Beauv. (Schläpfer and Fischer 1998). Kłyk (2005) reported a high level of diversity in terms of the generative offer in the genus Brachypodium. This offer is larger in perennials and smaller in B. distachyon; however, in the latter species chasmogamy, due to lodiculae activity, is common (Kosina and Pietrzak 2011; Kosina and Tomaszewska 2012). Sanders and Hamrick (1980) pointed out the importance of interaction between variation in breeding system and environment. They evidenced that in a self-fertilizing perennial, Elymus canadensis L., outcrossing is widely variable among populations. For pairs of autogamic grasses from the genera Avena L. and Bromus Scop., Jain (1979) proved that heterozygosity is higher in Avena barbata Pott ex Link and Bromus rubens L. than in A. fatua L., and B. mollis L. In these grasses, the rate of outcrossing is as high as several percent, but in Festuca microstachys Nutt., probably a cleistogamic species, it is $0 \%$ (Grant 1981). Allen and Meyer (2002) proved that interpopulational variation of germination traits in Bromus tectorum $\mathrm{L}$. exceeds $90 \%$. The breeding system of this grass is very close to that in B. distachyon.

In all perennial species of Brachypodium the anthers are remarkably extrorse, while in $B$. distachyon they are so in suitable weather conditions. In addition to dormancy and germination, variation in breeding system is the basis of the variation of all the features of any organism. Baskin and Baskin (2004) classified plants into the following five types of dormancy: physiological, morphological, morphophysiological, physical and combinational. The morphophysiological dormancy has been recognised as an ancestral state of seed plants and physiological dormancy as the most common (Willis et al. 2014). Seeds of annual cereals exhibit physiological dormancy. Naked grains, compared to hulled ones, have shorter dormancy (Grzesiuk and Kulka 1988). The situation is the same in the annual Brachypodium distachyon. The perennials of the genus Brachypodium seem to be different. However, before finding any answer, the most important factor is Baskin and Baskin's statement (Baskin and Baskin 2004) that dormancy is a typical quantitative multigenic characteristic expressed under the significant influence of environment.
The following review complements the data on relationships between variability of diaspore microstructure and dormancy-germination in various species of Brachypodium using original research results. Some comparisons to the members of the tribe Triticeae L. are also provided.

\section{A note on materials and methods}

The annual and perennial species of the genus Brachypodium were the research material for the review below. They are as follows:

- annual: B. distachyon (Bd, different accessions were numbered or marked by short symbols for the origin country),

- perennials: B. pinnatum (Bp), B. phoenicoides (L.) Roem. et Schult. (Bph), B. rupestre (Host) Roem. et Schult. (Br), B. sylvaticum (Bs) with additional markings such as for $B$. distachyon.

Among species of Brachypodium, only B. pinnatum has been used for breeding purposes (K. Hammer, pers. comm.).

Some references and comparisons were made to certain members of the tribe Triticeae, such as wheat, rye, goat-grass and amphiploids.

All the studied material, regardless of whether it was analysed in field plots or in Petri dishes, was tested under equal environmental conditions according to an experimental design in the form of the one-way classification of a completely randomized set, for small samples $(n=30)$. The breeding system was evaluated using several characters of anthers and pollen grains, as had previously been done by McKone (1985, 1987), Hammer (1987, 1990) and Kłyk (2005). Dormancy was tested in terms of the percentage of germination of diaspores and root growth rate at daily intervals. The details of microstructure were studied on caryopsis cross-sections or germinating diaspores under various microscopes: stereo-, Amplival polarizing (Carl Zeiss Jena) and an Olympus BX60 epifluorescence. Numerical analyses of multivariate data for operational taxonomic units (OTUs, accessions, species) were executed with the application of the non-metric multidimensional scaling method, nmMDS (Rohlf 1994) and according to Kruskal's proposal (Kruskal 1964). OTUs were plotted in a 3D-minimum-length spanning tree (MST) according to Rohlf's proposal (Rohlf 1981). 


\section{Variation in the Brachypodium breeding system}

Studies conducted by Kłyk (2005) evidenced that the breeding system of Brachypodium is variable within a broad range. Two extreme types of anther structure were described in Brachypodium (Kosina and Kłyk 2011; Kosina and Tomaszewska 2012). The first, displaying short anthers with few large pollen grains, is typical for the autogamic species, B. distachyon. The second one has long anthers with many small grains and is noted in allogamic species, e.g. B. pinnatum. A total of 271-582 pollen grains were developed in the anther of B. distachyon, while in B. pinnatum, a fully allogamic species, this range is between 5000 and 7640 grains. The highest developmental correlation ( $r=0.93$, significant for $\alpha=0.001$ ) exists between the length of anther and the number of pollen grains developed in it. Other examples of similar range of variation were discovered between annual autogamic versus perennial allogamic Hordeum vulgare $\mathrm{L}$. and $H$. bulbosum L. (Hammer 1976), Secale sylvestre Host and Secale cereale L. subsp. afghanicum (Vav.) Hammer, comb. nov. (Hammer et al. 1987), and between Bromus tectorum and Bromus inermis Leyss. (McKone 1989). In bromegrasses, the interplant variation was low in autogamic $B$. tectorum and high in allogamic $B$. inermis. The above mentioned developmental correlation evidences that pollen mother cells are arranged in one cell layer in anther sacs and any increase of the pollen grain number can be achieved by increasing the length of anther. Such a structure of grass anther sacs was presented by Bhandari (1984) and Batygina (1987). However, this pattern of anther development can be changed in grass hybrids or mutants. For instance, in an intermediate form between Avena sterilis subsp. sterilis L. and A. sterilis L. subsp. ludoviciana (Durieu) Gillet et Magne, numerous large pollen grains were formed in the long anthers (Kosina 2015).

All the species of Brachypodium express chasmogamy and this shows the possibility of intra- and interspecific hybridisation within the genus. Chasmogamy is very clear in all Brachypodium perennials. In $B$. distachyon, all the studied ecotypes are chasmogamic under moderate humidity and temperature (Kosina and Tomaszewska 2012). Vogel et al. (2009) suggest that polyploid ecotypes of $B$. distachyon are more chasmogamic than diploid ones in a greenhouse, but this is not confirmed in our collection under field conditions. Artificial hybrids between perennial highly chasmogamic species of Brachypodium have been obtained and have shown good fertility, but no seeds have been developed in hybrid plants between $B$. distachyon and related perennials (Khan and Stace 1999). Our last data prove that even spontaneous interspecific hybridization, including $B$. distachyon as a mother plant, is possible; however, a hybrid plant expressed complete $(100 \%)$ pollen grain sterility. Brachypodium phoenicoides was considered here to be a pollen donor (Kosina and Tomaszewska 2014b). Such a level of pollen sterility would not be possible after an intraspecific cross-pollination.

Auto-allogamy intervariability, chasmogamy versus cleistogamy, with many intermediate types between the extremes, was exemplified in many grasses. In bromegrasses, the anther length and total volume of pollen grains per anther have wide interplant variation in allogamic Bromus inermis, an intermediate range of variation in B. kalmii A. Gray, B. ciliatus L. and B. latiglumis (Shear) Hitchc. which expressed a moderate level of outcrossing and a narrow range of variation in a facultative obligatory selfer, B. tectorum (McKone 1987, 1989). Intraspecific variation of some characteristics of breeding system is well exemplified in cereals by intercultivar differences. The level of chasmogamy presented as the number of extrorsed anthers from the flower ranges from 1.42 to 2.88 among winter common wheat cultivars (Keydel 1972). The length of anther, being a good indicator of pollen grains quantity, ranges from 2.93 to 3.20 among cultivars of Hordeum vulgare (Hammer 1975). However, a successful pollination and seed setting can also depend on many environmental factors. For instance, irrigation caused a shift from chasmogamy to cleistogamy in B. rigidus Roth and B. diandrus Roth (Kon and Blacklow 1990). Such variability was also created seasonally and appeared even within a single inflorescence in $B$. carinatus Hook. et Arn. Stress conditions such as higher temperature and lower moisture or autumn weather induced cleistogamy in this bromegrass (Harlan 1945). The morning and afternoon temperatures and air humidity appeared to be the most favourable for chasmogamic flowering of many grasses (Kevan and Tikhmenev 1996).

Brachypodium distachyon and B. pinnatum are the most different in terms of breeding behaviour (see Fig. 1). Other perennial species, such as B. sylvaticum, 
Fig. 1 Minimum spanning tree of species of the genus Brachypodium in an ordination space created by the non-metric multidimensional scaling method, presenting the variation in the breeding system-autogamy versus allogamy. Symbols mark: Bd Brachypodium distachyon, Bs $B$. sylvaticum, Br B. rupestre, Bph B. phoenicoides, Bp B. pinnatum. Various accessions are numbered. Random data from an experiment made under equal environmental conditions; the same as for data presented in other figures

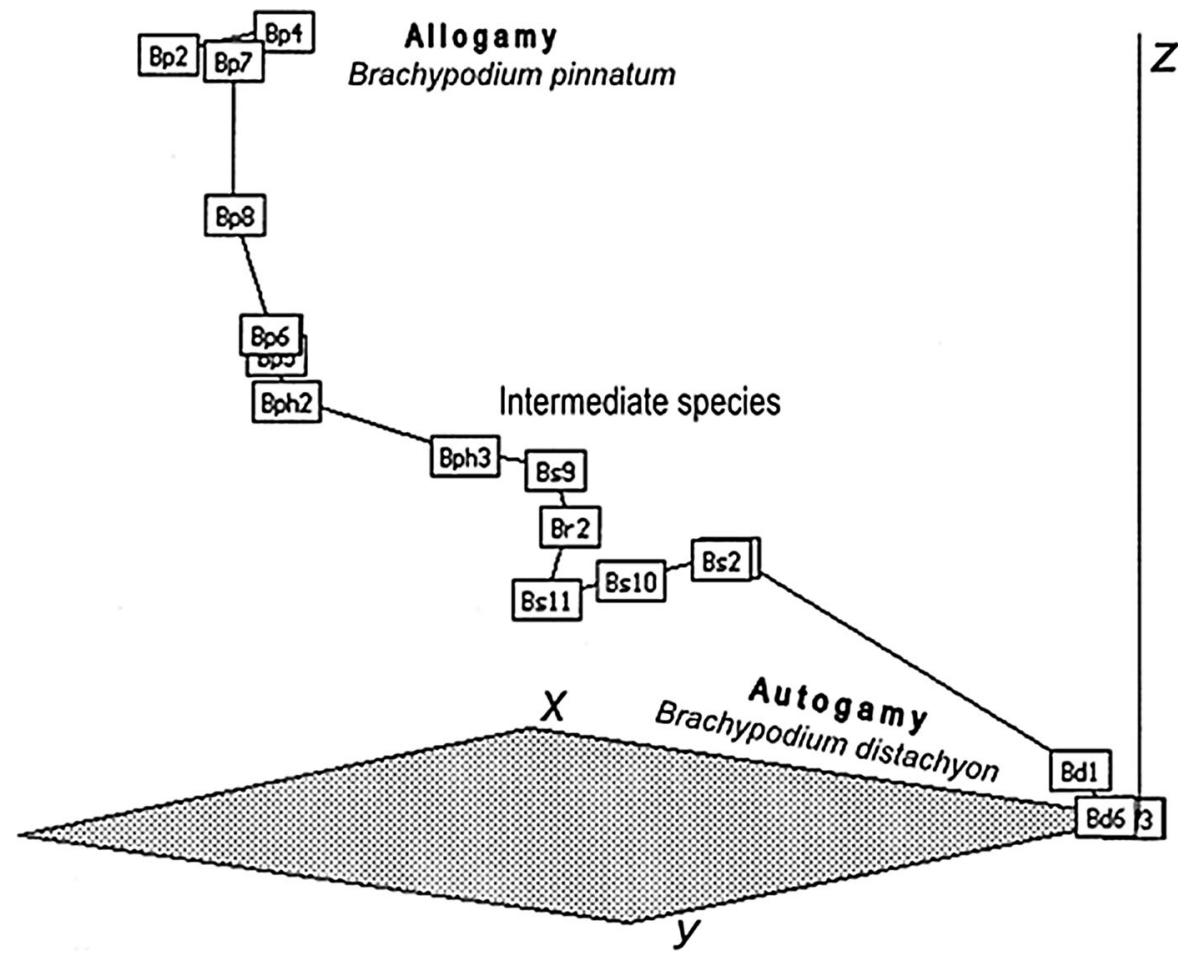

B. rupestre and B. phoenicoides, appeared to be intermediates between "pure" autogamic and allogamic units. The range of variation presented in Fig. 1 proves that in all populations of Brachypodium both auto- and allogamy are facultative. The level of facultativity depends strongly on weather conditions. In B. distachyon, cross-pollination, if it happens, will be expressed in the form of geitonogamy rather than allogamy and this depends on the anther and pollen grain behaviour during flowering in the species.

Thus, the level of heterozygosity in populations of Brachypodium will be high in allogamic B. pinnatum and species close to it, and proportionally lower in autogamic $B$. distachyon. This heterozygosity versus homozygosity, interacting with environment, will determine the patterns of all the variation in populations, including diaspore microstructures and levels of dormancy and germination dynamics. Andersson and Milberg (1998) studied variation in seed dormancy for three weed species belonging to three genera. They analysed dormancy between individual plants, between populations and between years; however, no mention was made of the breeding systems of these taxa. Therefore, their conclusions are seriously biased as a result of the lack of such information.
The above data show that in wild grasses, including Brachypodium, their life form seems to be correlated with breeding system, annuality with autogamy, and perenniality with allogamy. Such a linkage is also exemplified by Tsitsin's study on wheat $\mathrm{x}$ wheatgrass progeny (Tsitsin 1978). Perenniality together with chasmogamy was always inherited from the wheatgrass parent. However, perenniality also depends in hybrids on a parent genome dosage (Jones et al. 1999) and is expressed as a quantitative trait (Thomas et al. 2000). If linkage between life form and breeding system is strong, then in grass hybrids one can expect new intermediate variation of flowering behaviour, facultative selfing or outcrossing. In annual cereals, common wheat and rye do not support the above linkage.

\section{Variation in dormancy}

According to Barrero et al's considerations (Barrero et al. 2010) dormancy is recognized as a key character of adaptation for a specific ecological niche. Seeds expressing the different levels of dormancy, which are developed on a single plant, probably present the most 


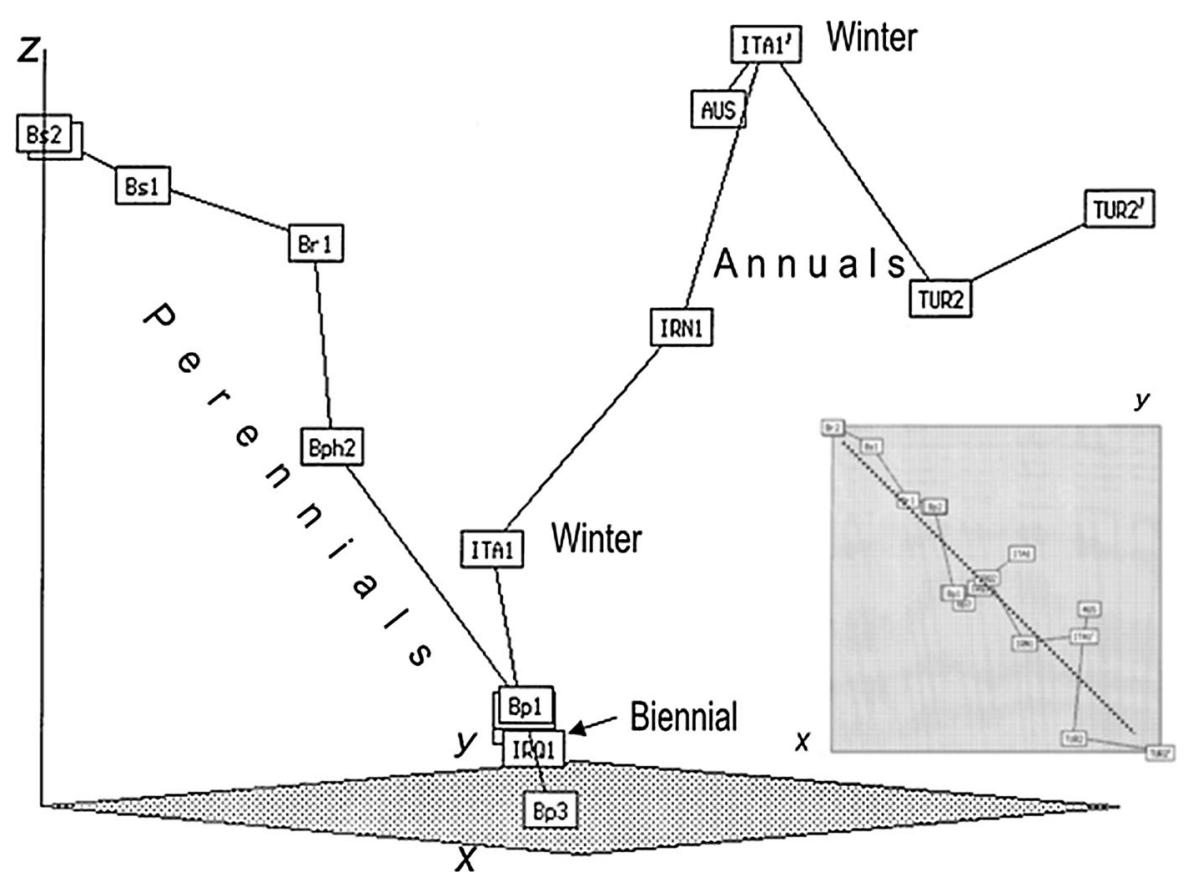

Fig. 2 Minimum spanning tree of species of the genus Brachypodium in an ordination space created by non-metric multidimensional scaling, presenting dormancy variation in annual and perennial ecotypes in Brachypodium. AUS, IRN, IRQ, ITA, TUR-accessions of B. distachyon. Pairs ITA1 versus ITA1' and TUR2 versus TUR2' express an inter-years of

remarkable pattern of variability. Diaspores can differ in dormancy pattern even in one spikelet, e.g. in wild wheats or oats (Mac Key 1989). In general, dormancy is a complex character created by many geneticenvironmental interactions. Light, temperature and water are the most important among environmental factors. The ratio between synthesis of abscisic acid (ABA) and gibberellins (GAs) determines dormancy and germination dynamics. The dormancy genes have been studied in the viviparous maize mutants and the high ABA level barley and rice. The expression of the dormancy genes is also regulated at the epigenetic level (Graeber et al. 2012). Lines with a high level of ABA have also been found in dormant $B$. distachyon (Barrero et al. 2012). A high level of synthesis of ABA in coleorhizal tissues has been found in barley (Barrero et al. 2009). In the domestication syndrome of plants, dormancy is significantly shortened and cereals are here an example. Wild $B$. distachyon, a species related to cereals, is a perspective taxon to find new genes of dormancy. A phylogenetic analysis based on the MOTHER OF FT AND TFLI (MFT) genes proved close relationships between $B$. storage variation. An insert diagram shows the top view of OTUs scattered on the $x, y$ axes plane. A group of OTUs is arranged along a highly significant regression line (dotted line). A correlation coefficient between values of both ordination axes is also highly significant $(r=0.89)$

distachyon and cereals, wheat and barley (Graeber et al. 2012). The $M F T$ genes, assumed to be a preharvest sprouting QTL, are located on chromosome 3 of Triticum aestivum L. (Nakamura et al. 2011). In wheat the dormancy genes (QTL) have also been found on chromosome 4A (Mares et al. 2005). Other dormancy genes have been identified in a wild wheat genome donor, Aegilops tauschii Coss. (Imtiaz et al. 2008). The level of dormancy also depends on the synthesis of phenolic acids, which has been documented in dormant versus pre-harvest sprouting wheat, rye and triticale (Weidner et al. 1999).

The Brachypodium dormancy in Fig. 2 was evaluated on the basis of the percentage of germination and root growth at several time intervals after diaspore (caryopsis enclosed in lemma and palea) imbibition. Patterns of dormancy variation between the years presented by Andersson and Milberg (1998) for three dicotyledonous weeds are also confirmed in Fig. 2. The variation between years of seed storage is marked by TUR and TUR' (an accession from Turkey) as well as ITA1 and ITA1' (an accession from Italy), pairs of two accessions of autogamic B. distachyon. The 
diaspores of early flowering accessions (TUR, AUS, IRN) of B. distachyon germinated quickly. B. sylvaticum (Bs1, Bs2) expressed the highest level of dormancy. Other perennials such as B. rupestre $(\mathrm{Br})$, B. phoenicoides (Bph) and B. pinnatum (Bp) have an intermediate dormancy. The positions in the diagram for winter (ITA) and facultatively biennial (IRQ, from Iraq) types of $B$. distachyon are noteworthy. They are close to the intermediate perennial types. Naked grains of $B$. distachyon germinated equally $24 \mathrm{~h}$ after imbibition, but those of $B$. sylvaticum were very dormant for at least several days.

A pattern of dormancy variation seen in Fig. 2 ( $z$ axis against $x+y$ ones) could probably be interpreted in the form of curvilinear regression of ordination axes; however, its picture (see an insert diagram in Fig. 2) presented for two ordination axes ( $x$ and $y$ ) is simpler. This variation is presented in the form of a diagonal dotted line of linear regression, extending from zero to maximal values of both axes. The minimal values of ordination axes are characteristic for perennial dormant types, and vice versa, maximal values are represented by non-dormant annuals. As mentioned above, it proves that the main part of dormancy variation shows a distinct trend between two extremes, dormant perennials, and nondormant annuals.

\section{Variation in grain structure versus dormancy}

Bewley and Black (1982) listed several roles attributed to pericarp and testa, which can restrict germination. They include interactions with water uptake and gaseous exchange, the activity of chemical inhibitors, light influence as well as a mechanical effect. For instance, the effect of light on the germination of $B$. distachyon was evidenced by Barrero et al. (2012). Adkins et al. (2002) highlighted several tissues causing dormancy in the grass diaspore. The decay of coat, as well as glumes and glumellae, removes dormancy. Grzesiuk and Kulka (1988) noted that even a small injury to covering tissues in cereals breaks dormancy. Cutting the testa and pericarp just in the area of the embryo-scutellum, Hou et al. (1997) enabled its rapid imbibition and break of dormancy in Avena fatua. The dormancy can also be expressed as mutifactorial with respect to the grain structure, e.g. in Themeda Forssk. The mechanical and chemical effect of glumellae on caryopsis germination was documented in Hordeum spontaneum (K. Koch) Thell. by Hamidi et al. (2009). Gatford et al. (2002) found some phenolic, i.e. vanillic acid, in bracts of Triticum tauschii (Aegilops tauschii Coss.), which distinctly inhibited germination. These authors suggest that $T$. tauschii, the D-genome donor to common wheat, can improve cultivated wheats against pre-harvest sprouting. The search for relevant genes should be performed within the available variability of this grass. Phenolics are also common in cereal caryopses (Naczk and Shahidi, 2006). The concentration of ferulic and sinapic acids in dormant cultivars of wheat, rye and triticale is distinctly higher than in those sprouting preharvest (Weidner et al. 1999). The phenolic acids (mainly ferulic acid) are linked to the $\beta$-glucans in the thick cell walls in the caryopsis of $B$. distachyon and their contents are similar to other cereals (Guillon et al. 2011). In wheat, $\beta$-glucans are synthesized in the cell walls of aleurone as well as subaleurone layers (Shewry et al. 2012). A particularly high concentration of the ferulic acid has been noted in the aleurone cell walls in wheat grain (Parker et al. 2005); however, this phenolic compound is mainly linked not to $\beta$-glucans but to arabinoxylan synthesized in the aleurone and transfer area of caryopsis (Robert et al. 2011).

An analysis of the pre-harvest sprouting white versus red wheats has proved that in the white cultivars the tissues of pericarp and integuments are looser and facilitate the rapid imbibition (Huang et al. 1983). However, the study of red seed coat common wheat mutants with white caryopses has shown that the red coat is not obligatory for dormancy expression; however, enhances it (Warner et al. 2000). In addition, $\mathrm{Gu}$ et al. (2011) discovered that a pleiotropic gene regulates $\mathrm{ABA}$ and flavonoid synthesis in pericarp of red-seeded rice. Such a genetic control makes it difficult to introduce dormancy genes into pre-harvest sprouting cultivars of rice with white pericarp. The ABA and flavonoids were accumulated in the adaxial epidermis of pericarp. In rice, the dormancy feature is even more complex, since the removal of pericarp does not eliminate it completely. Perhaps the most important discovery here is that dormancy alleles are different in tropical and temperate types of weedy rice. Such environment-dormancy relationships have also been well documented in wild barley, Hordeum spontaneum (Yan et al. 2008). Low dormancy was noted in mesic ecotypes, while deep dormancy was 
seen in xeric populations. The maximum germination ranged between 15 to 103 days. Another comparative genetic analysis of cultivated barley and wild Hordeum spontaneum proved that dormancy is linked to ten genomic regions and that some dormancy genes were lost during the domestication of this crop (Zhang et al. 2005). These results are very important for the consideration of dormancy variation within a set of the wild, weedy and cultivated forms. The wild and weedy forms have been described in B. distachyon (Kosina et al. 2011).

In rice, also the pigment strand, a tissue acting as a gate for the transport of assimilates into endosperm, is highly suberized (Oparka and Gates 1982); and consequently, the tissue acts as a barrier to water uptake and gaseous exchange. The dysfunction of the pigment strand has been evidenced in Aegilops umbellulata Zhuk. (Kosina 2014), while in a Triticeae amphiploid (T. timopheevii (Zhuk.) Zhuk. $\times$ Ae. umbellulata) suberization of this area is highly variable (Koźlik 2013).

As exemplified in Fig. 2, B. distachyon and $B$. sylvaticum are extremes in their dormancy patterns. Also the caryopsis structure of these species is very different. This is proved in Fig. 3-the caryopsis of $B$. distachyon is larger and has more hemicelluloses stored in the endosperm walls and in its very thick nucellar epidermis; however, Kosina and Kamińska (2013a) discovered an ample intraspecific variation in $B$. distachyon related to the assimilate storage capability in the starch and aleurone endosperm versus the nucellar epidermis. Some ecotypes of $B$. distachyon appeared to be structurally close to $B$. sylvaticum.

In $B$. distachyon hemicelluloses are composed mainly of feruloylated $\beta$-glucan (Guillon et al. 2011). An early synthesized part of a primary wall of this epidermis is composed of more cellulose, which can be detected with a polarizing microscope. An aleurone layer, a tissue of enzyme activity during germination, is composed of 1-3 layers of cells. In contrast, the caryopsis in B. sylvaticum and its hemicellulose potential in the cell walls is smaller. The aleurone tissue is most often composed of a onecelled layer. It has been proven that the thickness of the hemicellulosic nucellar epidermis is interaccessionally variable (Kosina and Jaroszewicz 2007; Jaroszewicz et al. 2012), but the difference between annuals and perennials is very distinct. So, the dynamics of germination depends on variation in the
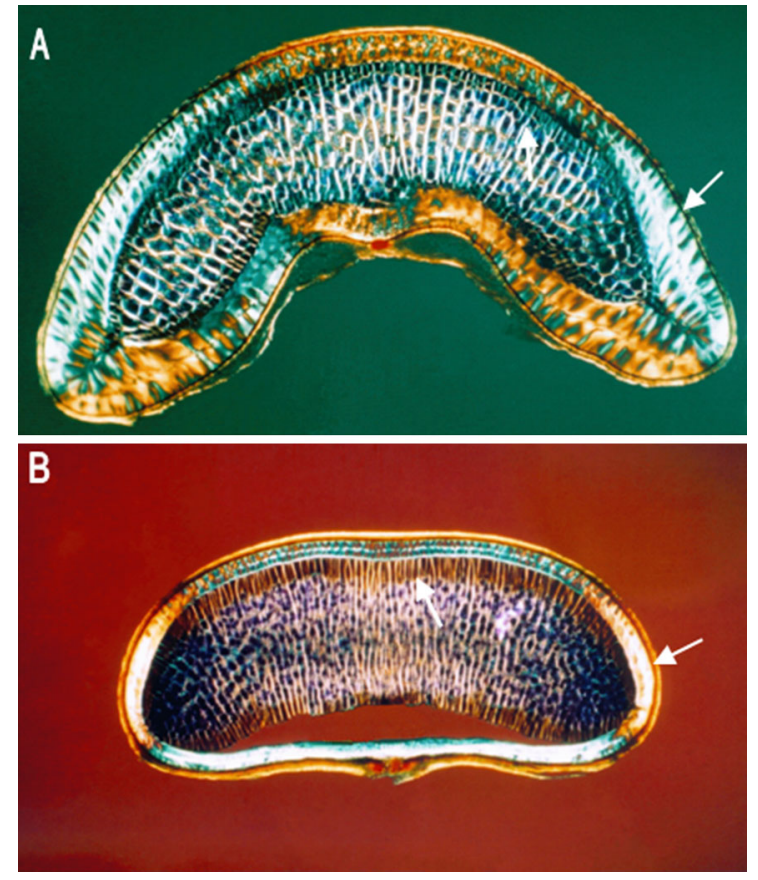

Fig. 3 Variability of caryopsis structure in the annual Brachypodium distachyon $(\mathbf{A})$ and perennial B. sylvaticum $(\mathbf{B})$. Arrows mark a nucellar epidermis and aleurone layer; pictures taken under the same magnification. (Color figure online)

aleurone layer structure, because it can be assumed that the layer composed of more cells radially arranged will quickly release more enzymes. Non-dormant Brachypodium species versus dormant ones also show different amounts of suberin and phenolics in testa and pigment strand (Fig. 4). In barley, Felker et al. (1984, 1985) proved that tannins are stored in vacuoles in pigment strand and testa, but in a necrotic mutant they are released into the cytoplasm. Kosina and Tomaszewska (2011), Kosina et al. (2013), Koźlik (2013) discovered that in an amphiploid Triticum L. $\times$ Aegilops L. a broad variation of pigment strand structure is expressed. This could also relate to all populations in which the recombination of parental genes exists.

Due to suberin and phenolics, the testa layer is highly impermeable to water and gaseous exchange. In $B$. distachyon the testa is sometimes discontinuous (see Fig. 5A); therefore, its role as a barrier will be decreased here. In B. pinnatum, a suberized testa is two-layered, light and dark brown (Fig. 5B) and its pigment strand is highly saturated by suberin and phenolics. This differentiation of the testa layers supports Kladnik et al's data (Kladnik et al. 2004). 

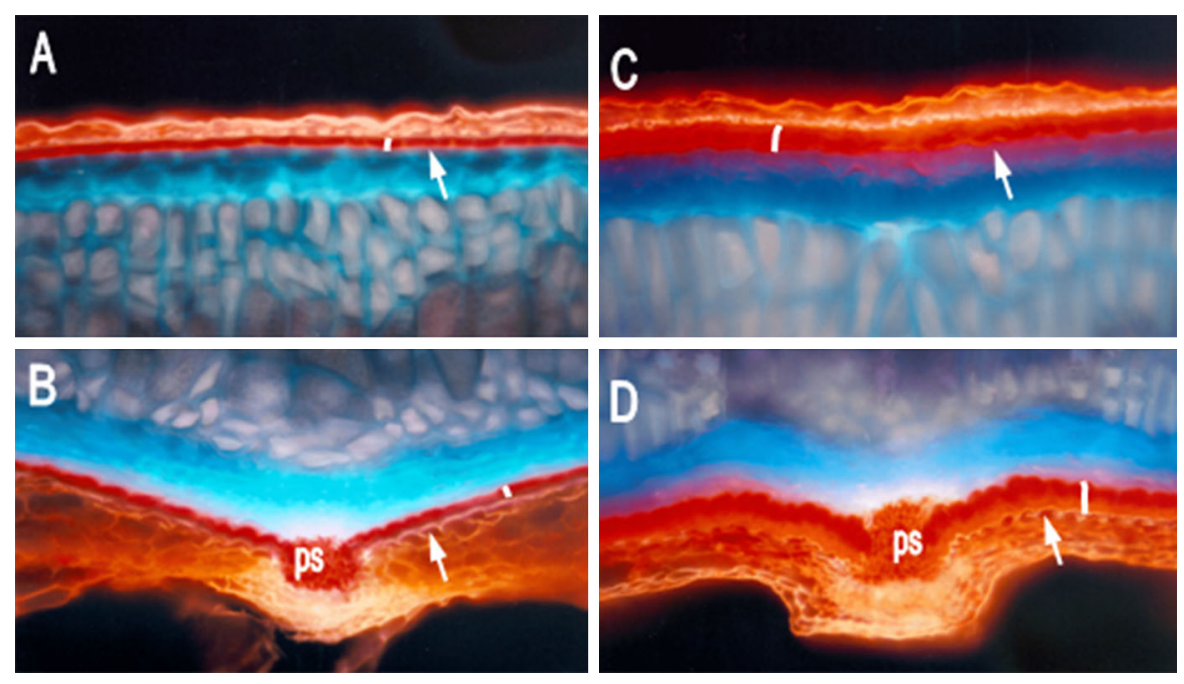

Fig. 4 Autofluorescence of covering layers of caryopsis Brachypodium distachyon $(\mathbf{A}, \mathbf{B})$ and B. sylvaticum $(\mathbf{C}, \mathbf{D})$. A, $\mathbf{C}$ a dorsal part; $\mathbf{B}, \mathbf{D}$ a ventral part. Fluorescence in Olympus $\mathrm{BX} 60$, a triplebandpass filter with maximum UV emission at
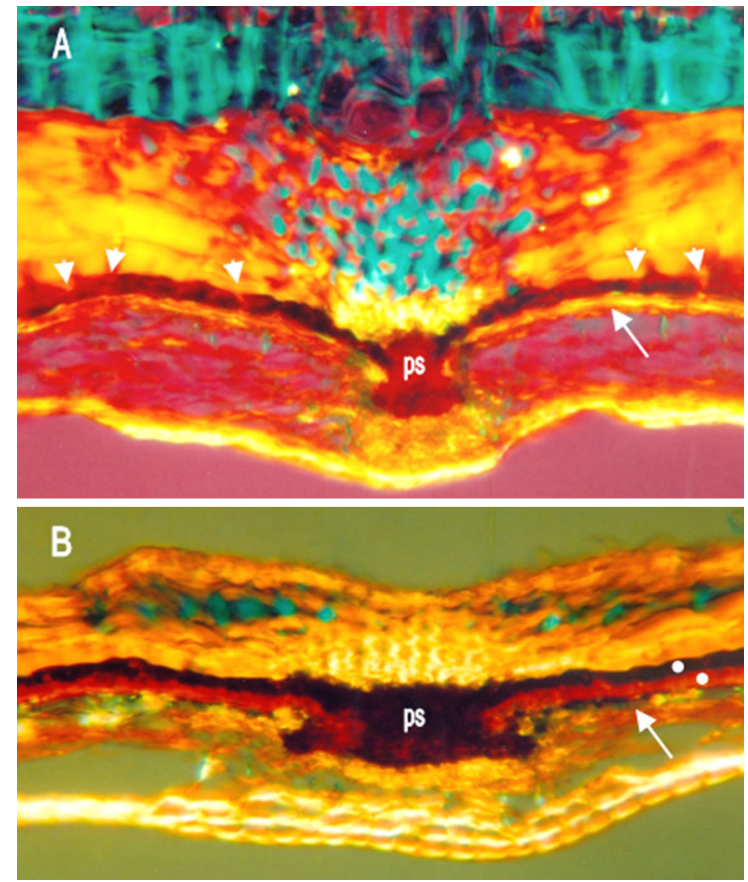

Fig. 5 Suberin-phenolic layer in testa (arrow) and pigment strand (ps) in Brachypodium distachyon (A) and B. pinnatum $(\mathbf{B})$. In B. distachyon the testa is discontinuous (arrowheads) and in $B$. pinnatum two-layered (light and dark brown, white dots); pictures taken under the same magnification. (Color figure online)
456, 520 and $572 \mathrm{~nm}$; pictures taken under the same magnification. Arrows show a suberized testa and its thickness is marked by white lines, $p s$ pigment strand. (Color figure online)

Probably, the most important factor for quick germination is the structure of caryopsis attachment to the lemma-palea base. Kladnik et al. (2004) found the different phenolics in a maize grain attachment structure. This area is free from suberin-phenolics in all ecotypes of annual B. distachyon (Fig. 6A). In perennials, the lemma-palea base is highly saturated by suberin-phenolics (Fig. 6B) and this saturation can be extended into lodicules (Fig. 6C). Detachment of glumellae distinctly improves the germination of perennials; however, its dynamics depends on the genotype of the plant. In perennials, with caryopses closed in glumellae, germination is sometimes only progressed by the coleoptile growth under the lemma and the root is stopped at the suberized glumellae base. Such a base restricts the flow of water into the coleorhiza, but water can be available through a pore at the top of the coleoptile. Such structural specificity in perennials could be recognized as a component of physical dormancy (Baskin and Baskin 2004) and this differs from that of the annual $B$. distachyon. In Setaria faberi Herrm. the similar variability of growth behaviour of the embryo components has been noted (Haar et al. 2014). There was only germination of coleoptile, or coleorhiza, or both together. 

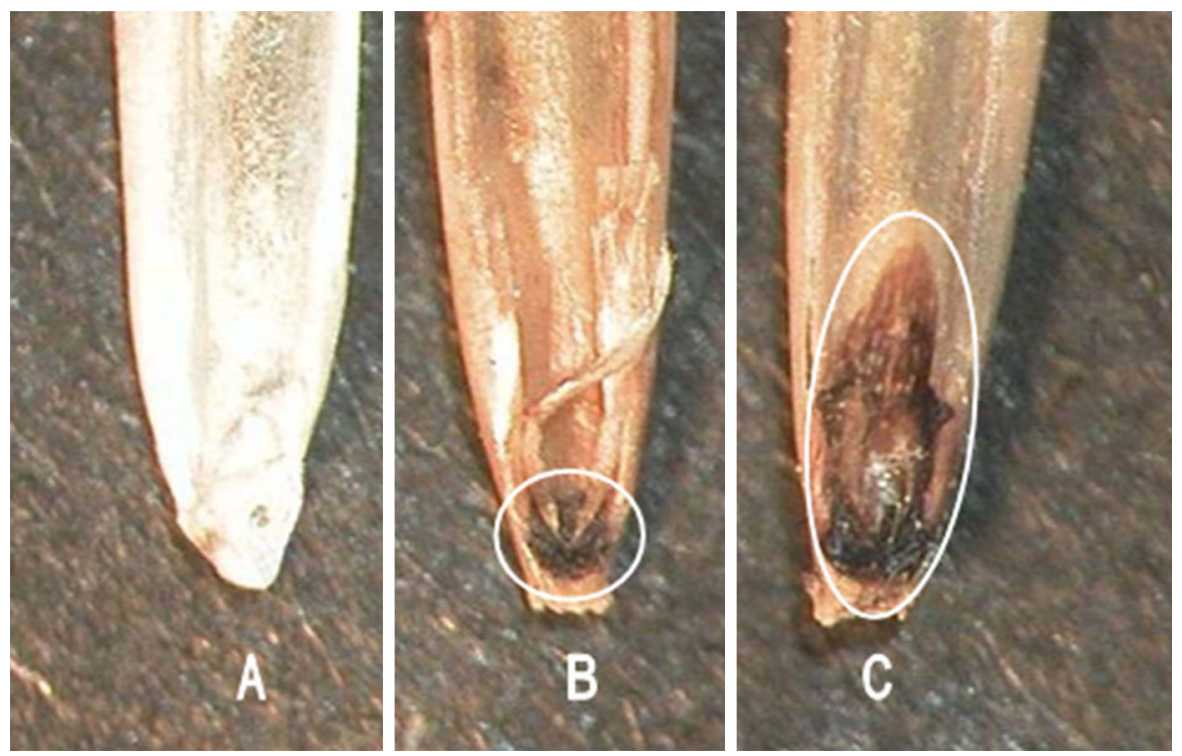

Fig. 6 A suberin-phenolic caryopsis attachment (outlined) in Brachypodium distachyon (A), B. sylvaticum (B) and B. phoenicoides (C). Pictures taken under the same magnification. (Color figure online)

In addition, several morphs of spikelet rachilla fragility have been detected in B. distachyon (Kosina et al. 2011; Jaroszewicz et al. 2012). This structural variability of a disarticulating scar is within the range of differences between wild and cultivated grasses. Such variability has also been noted in a wild Triticum dicoccoides (Körn. ex Asch. et Graebn.) Schweinf. (Poyarkova et al. 1991) as well as in fatuoid and nonfatuoid Avena sativa L. (Hoekstra et al. 2001). So, one can put a question whether the tissue of the disarticulating scar is variably suberized. If so, then an additional variation in dormancy and germination would be created.

\section{Variation in coleorhizal hairs-a germination structure}

The success of germination depends on many components of the diaspore, including some structural ones. One of these are coleorhizal hairs, which are a very special organ of grass caryopsis. They grow on the epidermis of coleorhiza, most often starting on its lateral sides as in Setaria faberi (Haar et al. 2014) and form a capillary sphere around the tip of an embryo. Their water uptake role was accepted a long time ago. In oats, the development of the coleorhizal hairs was distinctly promoted by oxygen (Norstog 1955). So, an aerated and humid capillary soil layer would be the best environment for the development of these hairs. The capillary potential will be larger when many long hairs are densely packed. In cases of high humidity water condenses on these hairs. Rost (1975) assigned the role of water absorption to the coleorhizal hairs in Setaria lutescens (Weigel ex Stuntz) F. T. Hubb. Northam et al. (1996) documented that in Taeniatherum caput-medusae (L.) Nevski from the tribe Triticeae development of coleorhizal hairs strongly depends on the germination temperature. At the end of the first $24 \mathrm{~h}$ of germination, at $18{ }^{\circ} \mathrm{C}, 15-74 \%$ of caryopses had these hairs. Water absorption and seedling anchoring functions have been attributed to them in Taeniatherum Nevski. Their anchoring role has also been documented for many surface-sown grasses (Morita et al. 1997). Bureś (2008) discovered that in two forms of an amphiploid Triticum dicoccum $\times$ Aegilops squarrosa (T. dicoccon Schrank. $\times$ Ae . tauschii Coss.) the development of coleorhizal hairs expresses distinct variability. An extremely preharvest sprouting form with white grains had long and dense hairs, but in another form, expressing no sprouting and having dark grains, the hairs were either poorer or absent. Kosina and Jaroszewicz (2007) presented a significant difference between the 

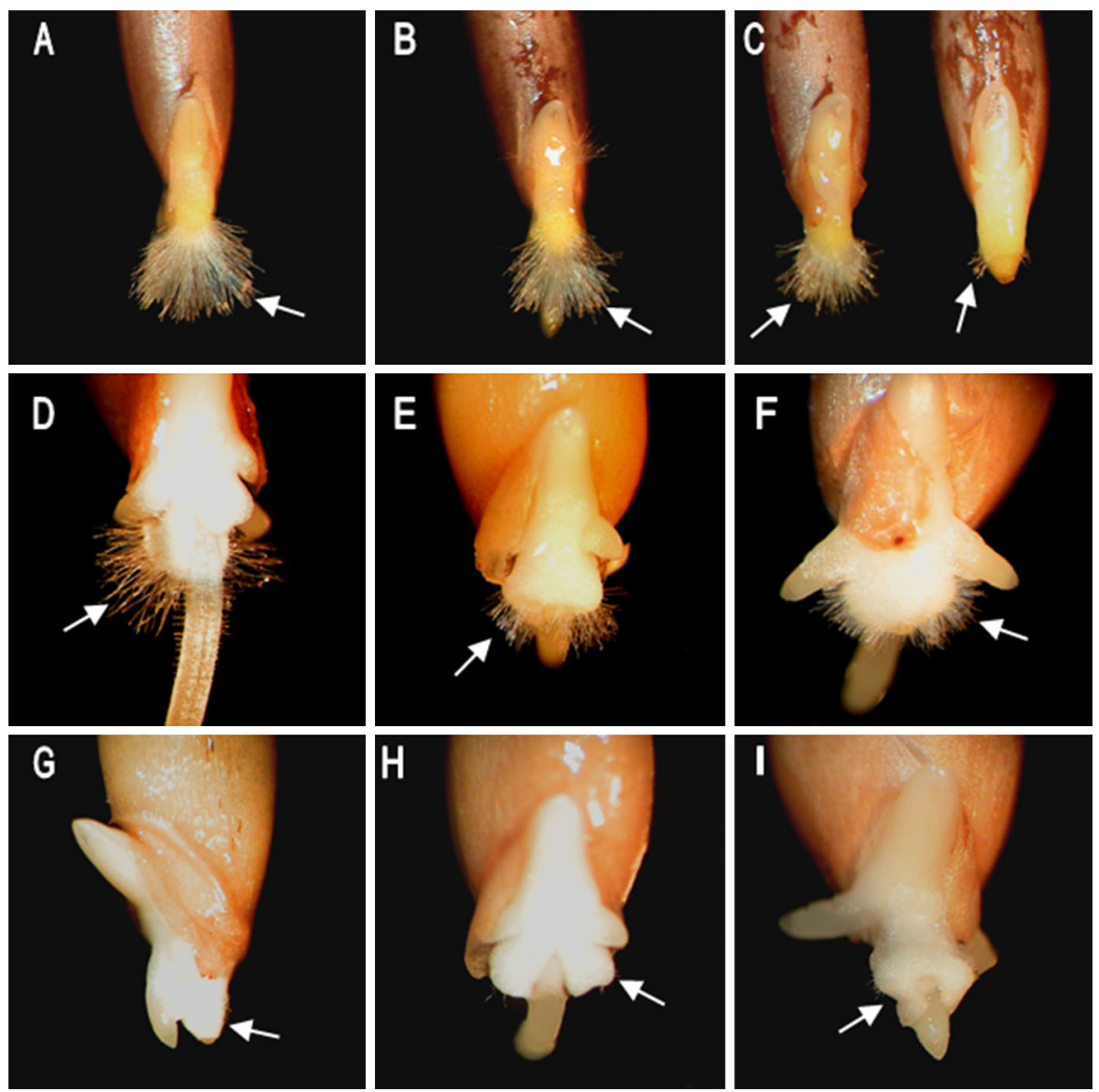

Fig. 7 Variability of coleorhizal hairs development in Brachypodium and some members of Triticeae. A Brachypodium distachyon (a spring accession IRN1), B B. distachyon (a spring/ winter accession ITA1), C B. distachyon (a facultatively

development of hairs in B. distachyon and B. sylvaticum. In the former, they are long and abundant. Also, in Setaria faberi the growth of hairs was variable and sometimes they were absent (Haar et al. 2014). Thus, the development of the hairs appears very variable.

In a monocotyledonous seedling, unicellular collar rhizoids create the first active contact between the embryo and the soil and gaseous environment (Tillich 2007). They develop on hypocotyl and coleorhiza and are homologous to the coleorhizal hairs presented here. The collar rhizoids are considered an ancestral character in the family Poaceae. Their absence is treated as a derived state.

The coleorhiza potential for germination is high not only due to water uptake by the hairs, but also via the synthesis of amyloplasts, as has been evidenced in biennial accession IRQ); D, G Secale cereale; $\mathbf{E}, \mathbf{H}$ Triticum aestivum; F, I T. fungicidum. D, E, F with hairs; G, H, I without hairs. Pictures taken under the same magnification $24 \mathrm{~h}$ after imbibition. (Color figure online)

barley (Davidson 1979). This storage capability of coleorhiza is also confirmed by the large amount of protein in the coleorhizal papilla in wheat and its amphiploids (Kosina 1995, 2007).

The coleorhizal hairs are very prominent in Brachypodium annuals (Fig. 7A, B); however, in the facultatively biennial form they are shorter and in some caryopses are absent (Fig. 7C). In species from the tribe Triticeae (Fig. 7D-I), the development of coleorhizal hairs is more variable. In general, they are shorter, less dense and often the tip of the coleorhiza is naked. They are rarely observed above the coleorhiza, in the area of hypocotyl. We can assume that their role in the quickly germinated seeds of cereals is lesser, while they are more important to maintain humidity around root in seeds of wild species such as Brachypodium, with slower germination and a slower 

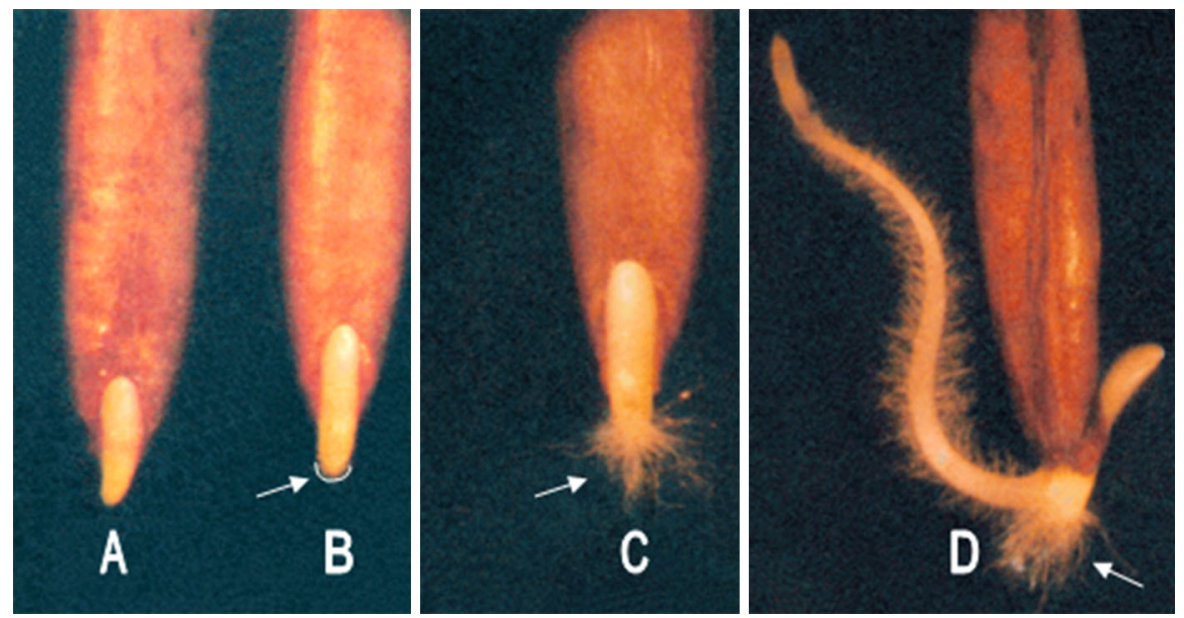

Fig. 8 Variability of the coleorhizal hairs development and dynamics of germination in the allogamic Brachypodium phoenicoides. Coleorhizal hairs are marked by arrows and in

seedling growth. The coleorhizal hairs are preserved over the many days of the seedling development.

These considerations should not neglect the intrapopulational variation of the coleorhizal hairs development (Fig. 8). For instance, in perennial and highly allogamic $B$. phoenicoides the variability ranges between slow germination and no coleorhizal hairs (Fig. 8A) and a vigorous seedling with abundant long hairs (Fig. 8D). Intermediate morphs also exist in the population (Fig. 8B, C). The presented variation, studied in the same environmental conditions, is formed by many genetic morphs and it may be described by the statistics of the continuous variation. This is evidence of population heterozygosity and multifactorial control of dormancy and germination.

The variation of the coleorhizal hairs is also expressed as the $0-1$ state (absent versus present), e.g. in Secale cereale L. or Aegilops umbellulata (Kosina and Tomaszewska 2014a). A maternal effect on the development of the coleorhizal hairs has been noted in an amphiploid progeny Triticum $\times$ Aegilops, reproduced from red or white caryopses (Kosina and Bureś 2014).

\section{Variation in germination}

Intra- and interspecific variation in germination

Relationships between the breeding system and the genetic variation it creates in the populations, as
B their sphere is outlined. Pictures taken under the same magnification 9 days after imbibition. (Color figure online)

discussed above, are exemplified by the intra- and interspecific variability of germination (see Fig. 9). In a given sample of germinating ripe diaspores of the allogamic Brachypodium phoenicoides we can observe a broad variability, from seedlings presenting a vigorous growth and those just beginning to germinate (Fig. 9A). Another accession (population, ecotype) of the same species presents slow germination and growth (Fig. 9B). The most dormant Brachypodium sylvaticum (see Fig. 2) also shows such a pattern of variation; however, germination of diaspores and growth of seedlings is distinctly weaker (Fig. 9C, D).

Intra- and interspecific variation of germination dynamics and root growth is also presented in Fig. 10. A rapid germination is noted for annuals and a late germination of dormant types is typical for perennials. Variation in embryo germination as a whole and its root growth is not correlated, because storage resources in caryopsis can be allocated to the root or to coleoptile, or to both organs simultaneously. In the highly dormant types (Bs, $\mathrm{Br}, \mathrm{Bph})$, germination can be at first realised by the development of a coleoptile under a lemma, while the root growth seems to be inhibited by a sclerified and suberized caryopsis attachment and a glumellae base. In addition, in the coleorhiza of barley, which is close to this attachment, a high level of ABA controlling dormancy has been detected (Barrero et al. 2009). Authors suggest that the ABA potential of coleorhiza is a barrier to root emergence. In the "coleoptile first" types of 

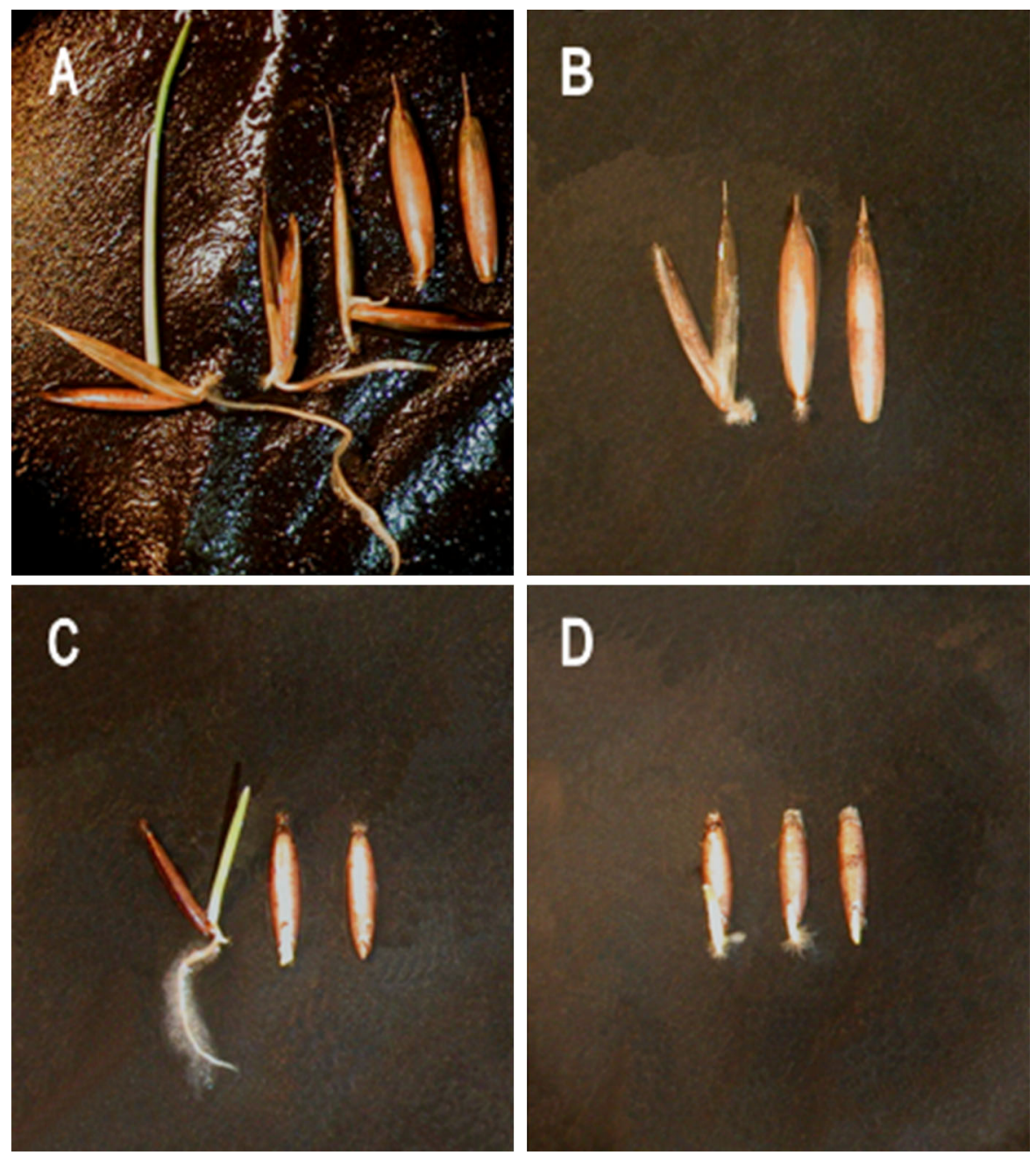

Fig. 9 Intra- and interspecific variability of germination in Brachypodium phoenicoides (A, $\mathbf{B}$ caryopses in lemma and palea) and $B$. sylvaticum (C, D naked caryopses). Pictures taken under the same magnification 9 days after imbibition. (Color figure online)

Fig. 10 Intra- and interspecific variation of germination dynamics in Brachypodium. A spring, $B$ winter, $C$ facultatively biennial, $D$ perennial; $\% / 1 \mathrm{~d}-\%$ of germination one day after imbibition; $\mathrm{rl} / 4 \mathrm{~d}$-length of root 4 days after imbibition; \%/7d-\% of germination 7 days after imbibition. (Color figure online)

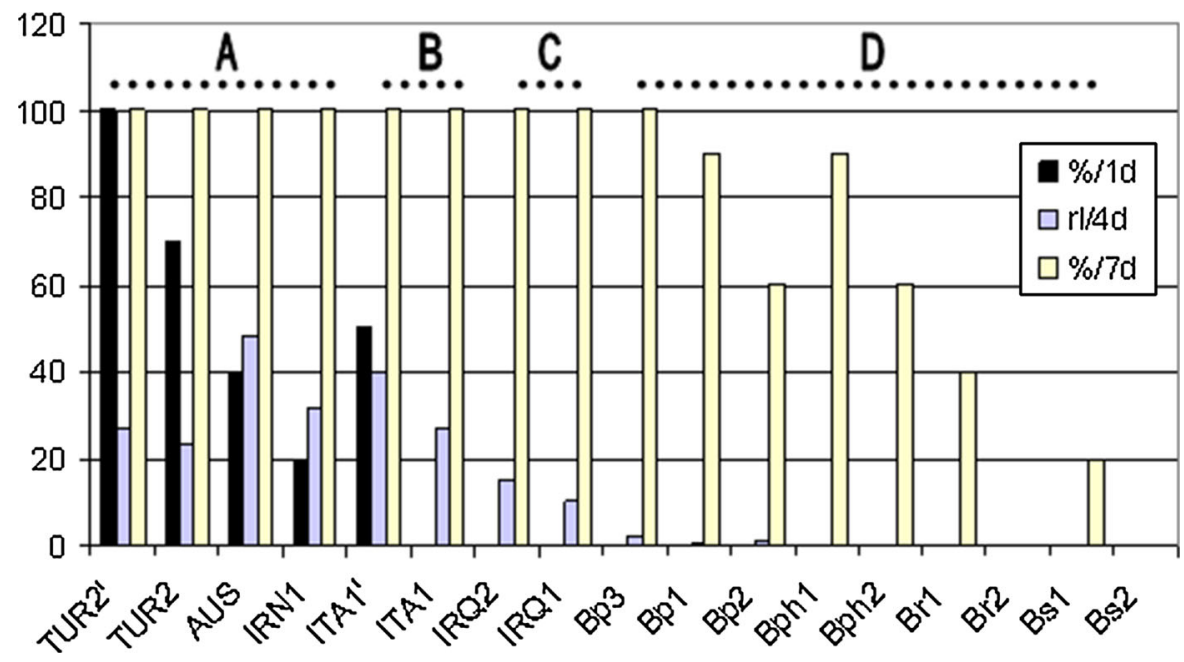


Brachypodium, it would be possible for there to be interaction between the coleorhizal $\mathrm{ABA}$ and the suberin-phenolic base of glumellae, and a blocking of the coleorhiza growth. Dakshini and Tandon (1970) reported the original germination in Oropetium thomaeum (L.f.) Trin., a grass growing in semi-arid habitats, in which the coleoptile growth was significantly earlier than that of coleorhiza. However, the authors did not consider the influence of a strongly suberized seed coat on the asymmetry of germination of two embryo organs. Such a coat covering the coleorhiza is distinctly evidenced in their data. In Setaria faberi, the growth of coleoptile and coleorhiza are recognized as two separate components of germination (Haar et al. 2014). The state of "the first shoot growth" was observed.

Intraspecific variation is documented by pairs of accessions in each species, for instance Bs1 and Bs2 for $B$. sylvaticum. Pairs of $B$. distachyon accessions, TUR2 vs TUR2' from Turkey and ITA1 vs ITA1' from Italy, show the influence of environment (years of storage) on germination. Winter and facultatively biennial types of $B$. distachyon appear to be intermediates between spring ecotypes of this species and the perennial species. The germination average taxonomic distance (the UPGMA method of clustering) is distinctly larger between accessions (populations) of B. distachyon than between populations of perennial species (Kosina and Tomaszewska 2014d)

The size of caryopsis also appears to affect dormancy and germination. The large caryopses in Hordeum spontaneum exhibited shallow dormancy and small ones germinated later (Yan et al. 2008). The same factor can modify germination in B. distachyon, because accessions in our collection vary highly in caryopsis size and assimilate storage potential (Jaroszewicz et al. 2012; Kosina and Kamińska 2013a). De facto, smaller caryopses expressed deeper dormancy (Kosina and Jaroszewicz 2007).

The above data are also important from the point of view of weed science. Some species of Brachypodium can become weeds or invasive plants in the case of today's climate change. This may relate in particular to B. distachyon (Bakker et al. 2009; Jaroszewicz et al. 2012). For weeds, the germination has to be discontinuous and internally controlled as well as possible in various environments (Baker 1974). Invasive populations of $B$. distachyon in California are highly differentiated and variation of their dormancy is expressed in the form of completely asynchronous germination (Bakker et al. 2009). Such a pattern of variation is well exemplified in Fig. 9 as well as in Fig. 10 (see the relationships between the percentage of germination and root length).

For Bromus sterilis L. and B. tectorum, which are species similar in their mating system and patterns of variability to the annual $B$. distachyon, a large interpopulational variation in dormancy has been evidenced; however, their weedy bahaviour was different, irrespective of dormancy similarity (Andersson et al. 2002). Inter-family variation of germination in populations of Bromus tectorum varies, depending on population geographical origin (Allen and Meyer 2002). In general, B. tectorum is considered an obligatory selfer, but occasionally it is cross-pollinated (Thill et al. 1984). Thus, the patterns of germination variation in $B$. distachyon can be modified, similarly as in B. tectorum, by its chasmogamy (Kosina and Tomaszewska 2012) with the possibility of intra- and interspecific hybridisation, which increases the level of heterozygosity (Kosina and Tomaszewska 2014b). B. tectorum is considered a winter grass (Thill et al. 1984; Beckstead et al. 1996), while in $B$. distachyon spring and winter forms have been described (Schwartz et al. 2010). Winter ecotypes of $B$. distachyon have various countries of origin in the Mediterrannean region, from Afghanistan to Italy (Kosina and Tomaszewska 2014c). So, studies into the dormancy in spring, winter and facultatively biennial types of $B$. distachyon could be particularly valuable for weed science.

\section{Brachypodium distachyon versus B. sylvaticum}

Populations of autogamic taxa are composed of one or several self-pollinated lines being near to homozygosity, while those of allogamic taxa are created by a set of few homozygotes and many heterozygotes. Thus, one can expect that in autogamic types the intrapopulational variation will be small and the interpopulational larger. In allogamic types the interpopulational variation is small. Jain's study (Jain 1979) shows that the above statement is a simplification; however, this difference is well presented in Fig. 11, where the interpopulational variation in germination is presented for the autogamic B. distachyon and allogamic B. sylvaticum. B. distachyon appeared to be a very suitable species for the rapid 
Fig. 11 Minimum spanning tree of two species of the genus Brachypodium in an ordination space created by the non-metric multidimensional scaling method (Rohlf 1994), presenting intra- and interspecific variation in dormancy and germination in Brachypodium distachyon and $B$. sylvaticum (dots mark various accessions). According to Kosina and Jaroszewicz (2007), modified

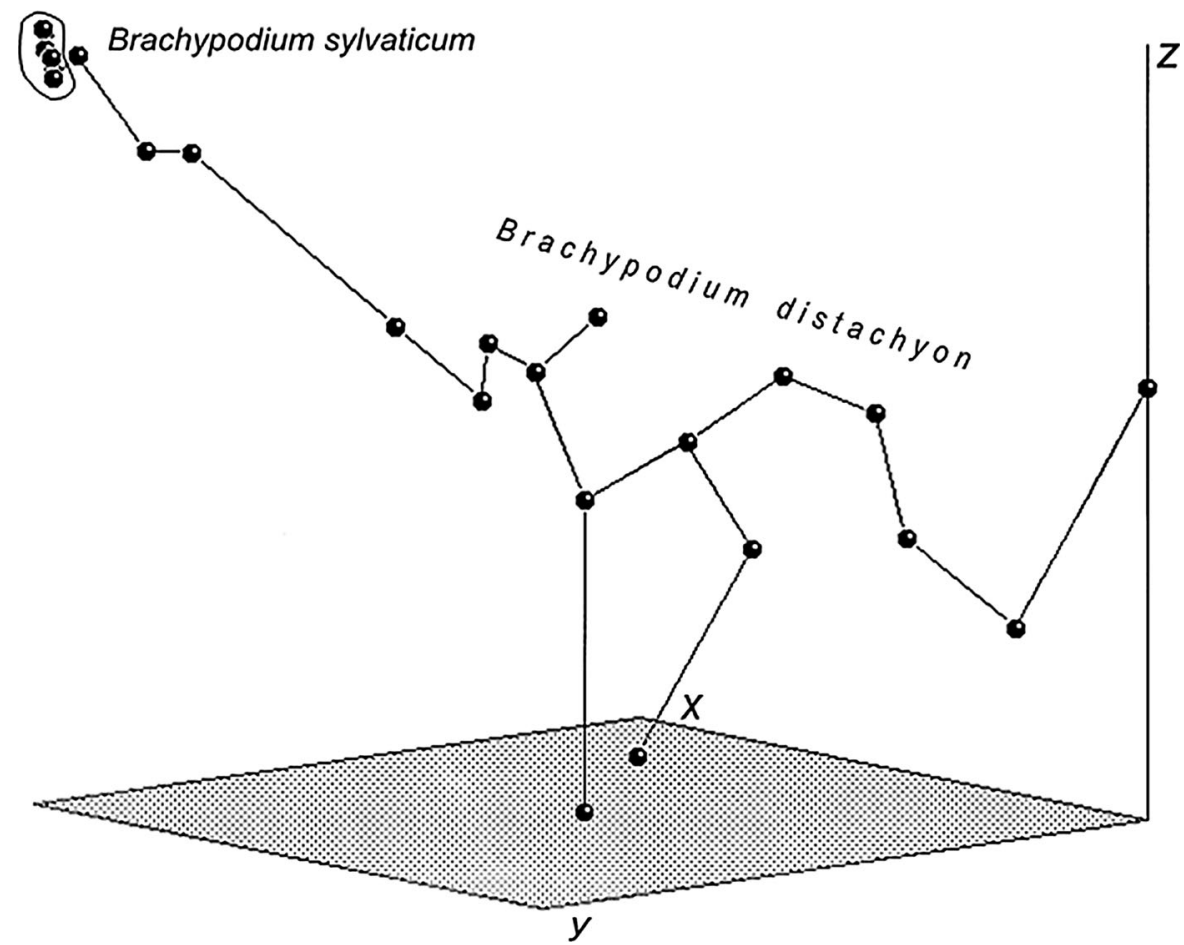

selection of differently dormant forms from a broad interaccessional variation; for instance, from early ripening spring, winter or facultatively biennial forms. The interaccessional (intraspecific) variability of germination in allogamic $B$. sylvaticum is distinctly smaller, as is also illustrated by Fig. 9C, D. Note that some accessions of $B$. distachyon expressing deeper dormancy are very close to a cluster of B. sylvaticum (Fig. 11).

The qualitative difference between $B$. distachyon and $B$. sylvaticum relates to shallow $v s$ deep dormancy. However, the difference between Bs1 and Bs2 (see Fig. 10) proves that in allogamic B. sylvaticum germination behaviour is also interaccessionally variable. B. distachyon is considered to be a facultatively autogamic unit (Kosina and Tomaszewska 2012), while B. sylvaticum is a self-compatible allogamic species (Khan and Stace 1999). However, data presented by Kłyk (2005) proved that the latter also expressed self-incompatible callosic reactions of pollen tubes. Thus, B. sylvaticum can be recognized as an intermediate species between $B$. distachyon and highly allogamic and self-incompatible ones, e.g. B. pinnatum (see Fig. 1). The facultative self-incompatibility of B. sylvaticum may facilitate intraspecific hybridization of its distant types. Such hybridization has been noted within invasive populations of this species in North America (Rosenthal et al. 2008). The study of intraspecific and interspecific patterns of dormancy and germination variation in both species (Kosina and Jaroszewicz 2007), and here proves to be particularly important, especially when B. sylvaticum is considered a model species in perennial grasses (Steinwand et al. 2013).

The role of hemicellulosic walls in germination

The accumulation of assimilates in the endosperm is dependent on the status of the transfer tissues (vascular bundle, pigment strand, nucellar projection) in the caryopsis. This transfer complex is highly variable in grasses of young hybrid origin (Kosina 2014). In $B$. distachyon, the assimilates are mainly stored in the form of starch and protein in endosperm and hemicelluloses in the cell walls of endosperm and nucellus. The ratio between starch, protein and hemicelluloses is intraspecifically variable both in the central endosperm (Kosina and Kamińska 2013b) and in the caryopsis as a whole (Kosina and Kamińska 2013a). The interspecific variation is also significant (Kłyk 
2005; Kosina and Jaroszewicz 2007, and here see Fig. 3). In seg barley mutants, a dysfunction of tannin vacuoles results in the phenolic saturation of the transfer complex, its necrosis and the abnormal development of endosperm (Felker et al. 1984, 1985). Such a change in the transfer complex hinders the imbibition of caryopsis across the crease.

The aleurone cell walls in Avena fatua contain noncellulosic polysaccharides, which have a great water capacity (Raju and Walther 1988). In wheat, these polysaccharides are in the form of $\beta$-glucan and arabinoxylan, and the latter is highly saturated with ferulic acid (Robert et al. 2011). The same status of endosperm cell has been documented for B. distachyon; however, in this species, differently than in cereals, the endosperm polysaccharides amount to up to $40 \%$, at the expense of starch. In B. distachyon the feruloylated arabinoxylan is located in the outer layers of the cell wall (Guillon et al. 2011). In the main temperate cereals, i.e. wheat, rye, oat and rye, the feruloylated arabinoxylan is concentrated in the nucellar epidermis and aleurone layer, while $\beta$-glucan is in subaleurone endosperm (Dornez et al. 2011). The different, slowly or quickly germinating, morphs of $B$. distachyon and B. sylvaticum are variable with respect to the thickness of the suberized testa and nucellar epidermis, and the number of cell rows in the aleurone layer (Kosina and Jaroszewicz 2007). Most likely, this variability is related to the amount of phenolic acid in arabinoxylan in the nucellar epidermis and aleurone cells. Here, it should be added that the aleurone layer develops, especially in hybrid forms, in the form of a mosaic of proteinaceous aleurone and starchy cells (Kosina 2007); then, the amount of ferulic acid will be reduced. This will create a new variation in dormancy and germination.

In the caryopses of all species of Brachypodium, the epidermis of the nucellus is formed by thick-walled cells. The walls are distinctly layered (see Fig. 12A) and the outer layers of the wall are more cellulosic and the inner ones are less so. Hemicelluloses ( $\beta$-glucans) are stored there (Guillon et al. 2011). It has been proved that this epidermis in B. distachyon is digested during germination (Kosina and Kamińska 2013c; see also Fig. 12A). The thick cell walls in the aleurone layer and starchy endosperm are also digested. For the perennial species, a smaller quantity of hemicelluloses is characteristic and this is also clearly visible when Fig. 3A is compared with Fig. 3B. Both the nucellar
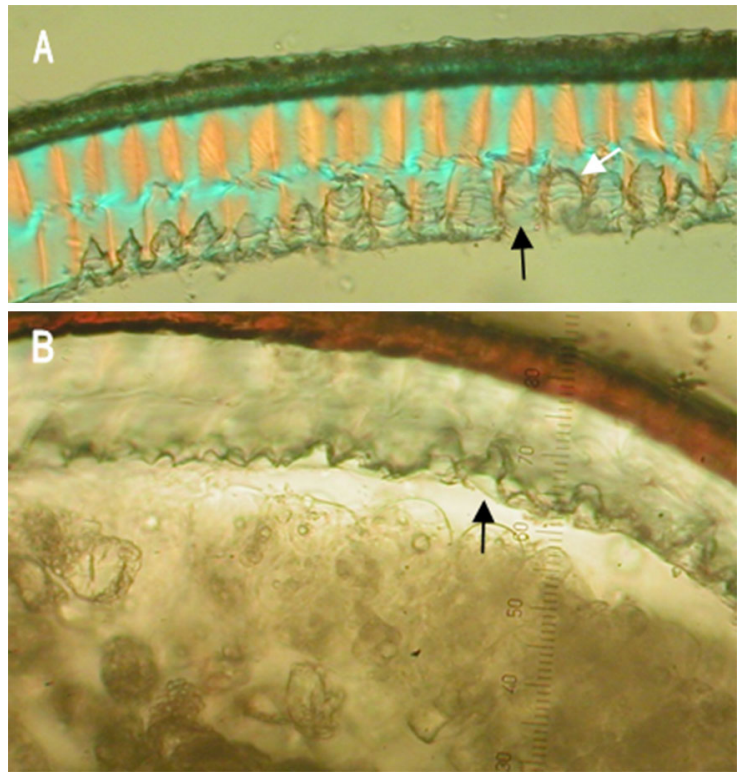

Fig. 12 Digestion of nucellar epidermis during germination in Brachypodium distachyon (A 14 days after imbibition) and $B$. pinnatum (B 19 days after imbibition). Internal hemicellulosic tangential walls of nucellar epidermis are layered (a white arrow) and first digested (black arrows). Adjacent aleurone layer and starchy endosperm are still visible in B. pinnatum, germinating later. Pictures taken under the same magnification of a polarizing microscope. (Color figure online)

epidermis and the cell walls of starchy endosperm are thinner. The quantity of hemicelluloses, in proportion to the starch, is higher in annuals than in perennials. We noted that when the cell walls of the nucellar epidermis are still preserved in a large quantity, starch and proteins in endosperm are significantly digested. The nucellar epidermis is first digested at the dorsal part of caryopsis, then progress to lateral sides. When the inner tangential walls are completely digested, the outer ones are fully preserved. Thin anticlinal walls, which are more cellulosic, are not digested (Fig. 12A). This proves that arabinoxylan and $\beta$-glucans are not uniformly synthesized in the cell wall around a protoplast. Such a pattern of wall digestion also indicates that the enzymatic activity is located in the adjacent aleurone layer.

\section{Concluding remarks}

Both groups of Brachypodium species, annuals and perennials, differ in their levels of allogamy. In $B$. distachyon, it is more restricted but possible, 
especially in the form of geitonogamy, due to the chasmogamy of flowers. This variation in breeding system creates the different patterns of dormancy and germination in populations of annuals versus perennials. However, in B. distachyon some winter and facultatively biennial forms are intermediate to the perennials. Both groups also differ with respect to their potential for cell wall hemicelluloses, as used during germination. The level of suberin-phenolic synthesis in the testa, pigment strand and caryopsis attachment is higher in the perennials and, very likely, chemically and physically influences their dormancy. The development of coleorhizal hairs is more variable within a heterozygotic population (an accession) of perennial species. This development also differs between the genus Brachypodium and the cereals of Triticeae. Finally, autogamic B. distachyon could be a good source for the selection of new types in terms of dormancy and germination. Filiz et al. (2009) proposed the expansion of the germ-plasm collection of B. distachyon in order to have its broad variation at our disposal. In such a collection we would also propose to maintain ecotypes exemplifying different dormancy, germination and winter hardiness, in the light of climate change and the present-day invasion of some Brachypodium species as new weeds. This broad variation of dormancy and germination in the germplasm collection will enable the study of these characteristics at the populational and mutational level. The species of Brachypodium could be a good model taxa for cereals, as was realized in Arabidopsis Heynh. for dicotyledonous plants by Koornneef et al. (2002).

Open Access This article is distributed under the terms of the Creative Commons Attribution 4.0 International License (http:// creativecommons.org/licenses/by/4.0/), which permits unrestricted use, distribution, and reproduction in any medium, provided you give appropriate credit to the original author(s) and the source, provide a link to the Creative Commons license, and indicate if changes were made.

\section{References}

Adkins SW, Bellairs SM, Loch DS (2002) Seed dormancy mechanisms in warm season grass species. Euphytica 126:13-20

Allen PS, Meyer SE (2002) Ecology and ecological genetics of seed dormancy in downy brome. Weed Sci 50:241-247
Andersson L, Milberg P (1998) Variation in seed dormancy among mother plants, populations and years of seed collection. Seed Sci Res 8:29-38

Andersson L, Milberg P, Schütz W, Steinmetz O (2002) Germination characteristics and emergence time of annual Bromus species of differing weediness in Sweden. Weed Res 42:135-147

Baker HG (1974) The evolution of weeds. Annu Rev Ecol Syst 5:1-24

Bakker EG, Montgomery B, Nguyen T, Eide K, Chang J, Mockler TC, Liston A, Seabloom EW, Borer ET (2009) Strong population structure characterizes weediness gene evolution in the invasive grass species Brachypodium distachyon. Mol Ecol 18:2588-2601

Barrero JM, Talbot MJ, White RG, Jacobsen JV (2009) Anatomical and transcriptomic studies of the coleorhiza reveal the importance of this tissue in regulating dormancy in barley. Plant Physiol 150:1006-1021

Barrero JM, Jacobsen J, Gubler F (2010) Seed dormancy: approaches for finding new genes in cereals. In: Pus EC, Dawey MR (eds) Plant developmental biology-biotechnological perspectives, vol 1. Springer, Berlin, pp 361-381

Barrero JM, Jacobsen JV, Talbot MJ, White RG, Swain SM, Garvin DF, Gubler F (2012) Grain dormancy and light quality effects on germination in the model grass Brachypodium distachyon. New Phytol 193:376-386

Baskin JM, Baskin CC (2004) A classification system for seed dormancy. Seed Sci Res 14:1-16

Batygina TB (1987) Chlebnoe zerno. Atlas, Nauka, Leningrad

Beckstead J, Meyer SE, Allen PS (1996) Bromus tectorum seed germination: between-population and between-year variation. Can J Bot 74:875-882

Bewley JD, Black M (1982) Physiology and biochemistry of seeds, vol 2. Springer, Berlin

Bhandari NN (1984) The microsporangium. In: Johri BM (ed) Embryology of Angiosperms. Springer, Berlin, pp 53-121

Bureś MK (2008) Analiza mikrostrukturalna ziarniaka wybranych amfidiploidów Triticeae. MSc thesis, Department of Cytogenetics and Plant Speciation, Institute of Plant Biology, University of Wrocław, Wrocław

Dakshini KMM, Tandon RK (1970) An unusual type of germination of a graminaceous seed. Ann Bot 34:423-425

Davidson D (1979) Coleorhiza, root and coleoptile emergence and growth: effects of different water volumes. Can J Plant Sci 59:61-67

Dornez E, Holopainen U, Cuyvers S, Poutanen K, Delcour JA, Courtin CM, Nordlund E (2011) Study of grain cell wall structures by microscopic analysis with four different staining techniques. J Cereal Sci 54:363-373

Felker FC, Peterson DM, Nelson OE (1984) Development of tannin vacuoles in chalaza and seed coat of barley in relation to early chalazal necrosis in the seg 1 mutant. Planta 161:540-549

Felker FC, Peterson DM, Nelson OE (1985) Anatomy of immature grains of eight maternal effect shrunken endosperm barley mutants. Am J Bot 72:248-256

Filiz E, Ozdemir BS, Budak F, Vogel JP, Tuna M, Budak H (2009) Molecular, morphological, and cytological analysis of diverse Brachypodium distachyon inbred lines. Genome 52:876-890 
Gatford KT, Eastwood RF, Halloran GM (2002) Germination inhibitors in bracts surrounding the grain of Triticum tauschii. Funct Plant Biol 29:881-890

Graeber K, Nakabayashi K, Miatton E, Leubner-Metzger G, Soppe WJJ (2012) Molecular mechanisms of seed dormancy. Plant, Cell Environ 35:1769-1786

Grant V (1981) Plant speciation. Columbia University Press, New York

Grzesiuk S, Kulka K (1988) Biologia ziarniaków zbóż. PWN, Warszawa

Gu X-Y, Foley ME, Horvath DP, Anderson JV, Feng J, Zhang L, Mowry CR, Ye H, Suttle JC, Kadowaki K, Chen Z (2011) Association between seed dormancy and pericarp color is controlled by a pleiotropic gene that regulates abscisic acid and flavonoid synthesis in weedy red rice. Genetics 189:1515-1524

Guillon F, Bouchet B, Jamme F, Robert P, Quéméner B, Barron C, Larré C, Dumas P, Saulnier L (2011) Brachypodium distachyon grain: characterization of endosperm cell walls. J Exp Bot 62:1001-1015

Haar M, van Aelst A, Dekker J (2014) Weedy adaptation in Setaria spp.: VIII. Structure of Setaria faberi seed, caryopsis and embryo. Preprint arXiv:1403.7096v1 [q-bio.QM]

Hamidi R, Mazaheri D, Rahimian H (2009) Wild barley (Hordeum spontaneum Koch) seed germination as affected by dry storage periods, temperature regimes, and glumellae characteristics. Iran J Weed Sci 5:1-12

Hammer K (1975) Die Variabilität einiger Komponenten der Allogamieneigung bei der Kulturgerste (Hordeum vulgare L. s.1.). Kulturpflanze 23:167-180

Hammer K (1976) Zur Allogamieneignung der Kulturgerste (Hordeum vulgare L.). Tag-Ber Akad Landwirtsch-Wiss DDR 143:221-226

Hammer K (1987) Resistenzmerkmale und Reproduktionssystem als Indikatoren für evolutionäre Tendenzen in der Gattung Aegilops L. Biol Zbl 106:273-282

Hammer K (1990) Breeding system and phylogenetic relationships in Secale L. Biol Zbl 109:45-50

Hammer K, Skolimowska E, Knüpffer H (1987) Vorarbeiten zur monographischen Darstellung von Wildpflanzensortimenten: Secale L. Kulturpflanze 35:135-177

Harlan JR (1945) Cleistogamy and chasmogamy in Bromus carinatus Hook. and Arn. Am J Bot 32:66-72

Hoekstra GJ, Darbyshire SJ, Mather DE (2001) Anatomical features at the disarticulation zone in florets of fatuoid and nonfatuoid oat (Avena sativa L.). Can J Bot 79:1409-1416

Hou JQ, Kendall EJ, Simpson GM (1997) Water uptake and distribution in non-dormant and dormant wild oat (Avena fatua L.) caryopses. J Exp Bot 48:683-692

Huang G, McCrate AJ, Varriano-Marston E, Paulsen GM (1983) Caryopsis structural and imbibitional characteristics of some hard red and white wheats. Cereal Chem 60:161-165

Imtiaz M, Ogbonnaya FC, Oman J, van Ginkel M (2008) Characterization of quantitative trait loci controlling genetic variation for preharvest sprouting in synthetic backcross-derived wheat lines. Genetics 178:1725-1736

Jain S (1979) Adaptive strategies: polymorphism, plasticity, and homeostasis. In: Solbrig OT, Jain S, Johnson GB, Raven $\mathrm{PH}$ (eds) Topics in plant population biology. Columbia University Press, London, pp 160-187
Jaroszewicz AM, Kosina R, Stankiewicz PR (2012) RAPD, karyology and selected morphological variation in a model grass, Brachypodium distachyon. Weed Res 52:204-216

Jones TA, Zhang X-Y, Wang RR-C (1999) Genome characterization of MT-2 perennial and OK-906 annual wheat $\mathrm{X}$ intermediate wheatgrass hybrids. Crop Sci 30:1041-1043

Kevan PG, Tikhmenev EA (1996) Dynamic anemophily and the ecology of pollination in common grasses in Ontario. Russ J Ecol 27:260-266

Keydel F (1972) Blütenbiologische Untersuchungen: 1. Die Offenblütigkeit verschiedener Winterweizensorten. Bayer Landw Jahrbuch 49:688-701

Khan MA, Stace CA (1999) Breeding relationships in the genus Brachypodium (Poaceae: Pooideae). Nord J Bot 19:257-269

Kladnik A, Chamusco K, Dermastia M, Chourey P (2004) Evidence of programmed cell death in post-phloem transport cells of the maternal pedicel tissue in developing caryopsis of maize. Plant Physiol 136:3572-3581

Kłyk B (2005) Zmienność mikrostrukturalna niektórych gatunków rodzaju Brachypodium P. Beauv. PhD thesis, University of Wrocław, Wrocław

Kon KF, Blacklow WM (1990) Polymorphism, outcrossing and polyploidy in Bromus diandrus and B. rigidus. Aust J Bot 38:609-618

Koornneef M, Bentsink L, Hilhorst H (2002) Seed dormancy and germination. Curr Opin Plant Biol 5:33-36

Kosina R (1995) Tetraploids of the genus Triticum in the light of caryopsis structure. Acta Universitas Wratislaviensis 1785, Prace Botaniczne 66. University of Wrocław, Wrocław

Kosina R (2007) Some topics on the grass mosaics. In: Frey L (ed) Biological issues in grasses. W. Szafer Institute of Botany, Polish Academy of Sciences, Kraków, pp 159-167

Kosina R (2014) On caryopsis xylem and its interactions. In: Berhardt LV (ed) Advances in medicine and biology, vol 75. Nova Science Publishers, New York, pp 43-63

Kosina R (2015) Variation of reproduction in some species of the tribe Aveneae (Poaceae). Mod Phytomorphol 8:11-14

Kosina R, Bureś M (2014) Variability in germination in Triticum diccocum/Aegilops squarrosa amphiploids. Ann Wheat Newslet 60:115-116

Kosina R, Jaroszewicz A (2007) Mikrostrukturalne determinanty kiełkowania ziarniaków Brachypodium distachyon i B. sylvaticum (Poaceae). Fragmenta Floristica et Geobotanica Polonica, Suppl. 9: 117-125

Kosina R, Kamińska K (2013a) Variability of caryopsis micromorphology in Brachypodium distachyon. Ann Wheat Newslet 59:125-126

Kosina R, Kamińska K (2013b) Structural types of endosperm in Brachypodium distachyon. Ann Wheat Newslet 59:124-125

Kosina R, Kamińska K (2013c) The role of nucellar epidermis during the germination of Brachypodium distachyon. Ann Wheat Newslet 59:124

Kosina R, Kłyk B (2011) Reproduction in Brachypodium distachyon and related species. Ann Wheat Newslet 57:251-252

Kosina R, Pietrzak K (2011) Lodicule micromorphology in an autogamic grass, Brachypodium distachyon. Ann Wheat Newslet 57:253-254 
Kosina R, Tomaszewska P (2011) Contribution on Avena (Poaceae) amphiploids endosperm. In: Frey L (ed) Advances in grass biosystematics. W. Szafer Institute of Botany, Polish Academy of Sciences, Kraków, pp 119-127

Kosina R, Tomaszewska P (2012) On breeding system in wheat and Brachypodium distachyon. Ann Wheat Newslet 58:194-195

Kosina R, Tomaszewska P (2014a) Variability of coleorhizal hairs in Triticeae and Brachypodium. Ann Wheat Newslet 60:110-112

Kosina R, Tomaszewska P (2014b) Questions about the nature of an anomalous plant in Brachypodium distachyon. Ann Wheat Newslet 60:109-110

Kosina R, Tomaszewska P (2014c) Interpopulational and interspecific variation of germination in Brachypodium. Ann Wheat Newslet 60:113-114

Kosina R, Kłyk B, Florek M (2011) On variability of the weedy characteristics in a model grass, Brachypodium distachyon. Ann Wheat Newslet 57:249-250

Kosina R, Koźlik A, Markowska K (2013) Variability of pigment strand in a 'Triticum timopheevii subsp. timopheevii/ Aegilops umbellulata' amphiploid and related species. Ann Wheat Newslet 59:115-116

Koźlik A (2013) Zmienność mikrostrukturalna owocu amfiploida Triticum timopheevii x Aegilops umbellulata. MSc thesis, Institute of Experimental Biology, University of Wrocław, Wrocław

Kruskal JB (1964) Multidimensional scaling by optimizing goodness of fit to a nonmetric hypothesis. Psychometrika 29:1-27

Mac Key J (1989) Seed dormancy in wild and weedy relatives of cereals. In: Derera NF (ed) Preharvest field sprouting in cereals. CRC Press, Boca Raton, pp 15-25

Mares D, Mrva K, Cheong J, Williams K, Watson B, Storlie E, Sutherland M, Zou Y (2005) A QTL located on chromosome 4A associated with dormancy in white- and redgrained wheats of diverse origin. Theor Appl Genet 111:1357-1364

McKone MJ (1985) Reproductive biology of several bromegrasses (Bromus): breeding system, pattern of fruit maturation, and seed set. Am J Bot 72:1334-1339

McKone MJ (1987) Sex allocation and outcrossing rate: a test of theoretical predictions using bromegrasses (Bromus). Evolution 41:591-598

McKone MJ (1989) Intraspecific variation in pollen yield in bromegrass (Poaceae: Bromus). Am J Bot 76:231-237

Morita O, Ehara H, Goto M (1997) Anchoring function of coleorhiza hairs and seedling establishment of surfacesown forage grasses. Grassl Sci 42:277-282

Naczk M, Shahidi F (2006) Phenolics in cereals, fruits and vegetables: occurrence, extraction and analysis. J Pharmaceut Biomed 41:1523-1542

Nakamura S, Abe F, Kawahigashi H, Nakazono K, Tagiri A, Matsumoto T, Utsugi S, Ogawa T, Handa H, Ishida H, Mori M, Kawaura K, Ogihara Y, Miura H (2011) A wheat homolog of MOTHER OF FT AND TFL1 acts in the regulation of germination. Plant Cell 23:3215-3229

Norstog KJ (1955) Responses of the oat coleorhiza to various treatments in culture. Ohio J Sci 55:340-342
Northam FE, Callihan RH, Puchalski MM (1996) Coleorhizal hairs in germinating medusahead (Taeniatherum caputmedusae). Weed Sci 44:884-889

Oparka KJ, Gates PJ (1982) Ultrastructure of the developing pigment strand of rice (Oryza sativa L.) in relation to its role in solute transport. Protoplasma 113:33-43

Parker ML, Ng A, Waldron KW (2005) The phenolic acid and polysaccharide composition of cell walls of bran layers of mature wheat (Triticum aestivum L. cv. Avalon) grains. J Sci Food Agric 85:2539-2547

Poyarkova H, Gerechter-Amitai ZK, Genizi A (1991) Two variants of wild emmer (Triticum dicoccoides) native to Israel: morphology and distribution. Can $\mathrm{J}$ Bot 69:2772-2789

Raju MVS, Walther A (1988) Heterogeneity and behaviour of aleurone cells in the caryopsis of wild oats (Avena fatua). Flora 180:417-427

Richards AJ (1986) Plant breeding systems. George Allen \& Unwin, London

Robert P, Jamme F, Barron C, Bouchet B, Saulnier L, Dumas P, Guillon F (2011) Change in wall composition of transfer and aleurone cells during wheat grain development. Planta 233:393-406

Rohlf FJ (1981) Spatial representation of phylogenetic trees computed from dissimilarity matrices. In: International symposium on concept and method in paleontology, Barcelona, pp 303-311

Rohlf FJ (1994) NYSYS-pc v. 1.80. Applied Biostatistics Inc, New York

Rosenthal DM, Ramakrishnan AP, Cruzan MB (2008) Evidence for multiple sources of invasion and intraspecific hybridization in Brachypodium sylvaticum (Hudson) Beauv. in North America. Mol Ecol 17:4657-4669

Rost TL (1975) The morphology of germination in Setaria lutescens (Gramineae): the effects of covering structures and chemical inhibitors on dormant and non-dormant florets. Ann Bot 39:21-30

Sanders TB, Hamrick JL (1980) Variation in the breeding system of Elymus canadensis. Evolution 34:117-122

Schläpfer F, Fischer M (1998) An isozyme study of clone diversity and relative importance of sexual and vegetative recruitment in the grass Brachypodium pinnatum. Ecography 21:351-360

Schwartz CJ, Doyle MR, Manzaneda AJ, Rey PJ, Mitchell-Olds T, Amasino RM (2010) Natural variation of flowering time and vernalization responsiveness in Brachypodium distachyon. Bioenerg Res 3:38-46

Shewry PR, Mitchell RAC, Tosi P, Wan Y, Underwood C, Lovegrove A, Freeman J, Toole GA, Mills ENC, Ward JL (2012) An integrated study of grain development of wheat (cv. Hereward). J Cereal Sci 56:21-30

Steinwand MA, Young HA, Bragg JN, Tobias CM, Vogel JP (2013) Brachypodium sylvaticum, a model for perennial grasses: transformation and inbred line development. PLoS ONE 8:1-11

Thill DC, Beck KG, Callihan RH (1984) The biology of downy brome (Bromus tectorum). Weed Sci 32(1):7-12

Thomas H, Thomas HM, Ougham H (2000) Annuality, perenniality and cell death. J Exp Bot 51:1781-1788 
Tillich H-J (2007) Seedling diversity and the homologies of seedling organs in the order Poales (Monocotyledons). Ann Bot 100:1413-1429

Tsitsin NV (1978) Mnogoletnyaya pshenitsa. Nauka, Moskva

Vogel JP, Tuna M, Budak H, Huo N, Gu YQ, Steinwand MA (2009) Development of SSR markers and analysis of diversity in Turkish populations of Brachypodium distachyon. BMC Plant Biol 9: 88 doi:10.1186/1471-2229-988. Available at: http://www.biomedcentral.com/14712229/9/88

Warner RL, Kudrna DA, Spaeth SC, Jones SS (2000) Dormancy in white-grain mutants of Chinese Spring wheat (Triticum aestivum L.). Seed Sci Res 10:51-60

Weidner S, Amarowicz R, Karamać M, Dąbrowski G (1999) Phenolic acids in caryopses of two cultivars of wheat, rye and triticale that display different resistance to pre-harvest sprouting. Eur Food Res Technol 210:109-113
Willis CG, Baskin CC, Baskin JM, Auld JR, Venable DL, Cavender-Bares J, Donohue K, Rubio de Casas R (2014) The evolution of seed dormancy: environmental cues, evolutionary hubs, and diversification of the seed plants. New Phytol 203:300-309

Yan J, Chen G, Cheng J, Nevo E, Gutterman Y (2008) Phenotypic variation in caryopsis dormancy and seedling salt tolerance in wild barley, Hordeum spontaneum, from different habitats in Israel. Genet Resour Crop Evol 55:995-1005

Zhang F, Chen G, Huang Q, Orion O, Krugman T, Fahima T, Korol AB, Nevo E, Gutterman Y (2005) Genetic basis of barley caryopsis dormancy and seedling desiccation tolerance at the germination stage. Theor Appl Genet 110:445-453 